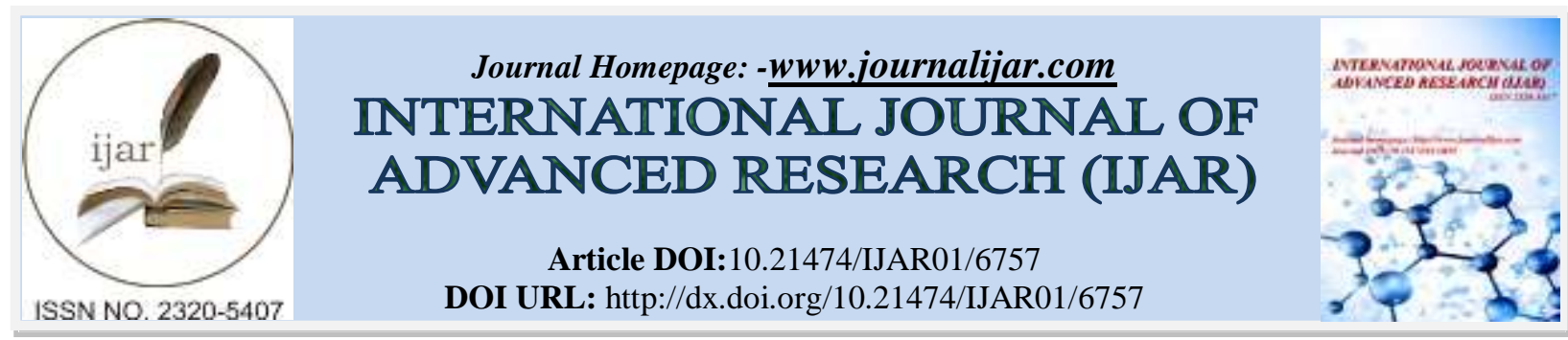

RESEARCH ARTICLE

\title{
PERFORMANCE OF INDIAN POST OFFICE SAVING SCHEMES IN RECENT TRENDS.
}

\author{
K. Baby saranya ${ }^{1}$ and "Dr. R. Hamsalakshmi². \\ 1. Assistant professor Commerce Department texcity Arts and science college, Coimbatore-105. \\ 2. Assistant professor, PG and Research Department of Commerce LRG Government Arts College for Women, \\ Tirupur-04.
}

\section{Manuscript Info}

Manuscript History

Received: 16 January 2018

Final Accepted: 18 February 2018

Published: March 2018

\section{Abstract}

Copy Right, IJAR, 2018,. All rights reserved.

\section{Introduction of Indian post office:-}

Savingsshapes the important part of the economy of any nation. With the savings, in various options available to the people, the money acts as the driver for growth of the country. Indianfinancial prospect toopresents a plethora of avenues to the investors. Thoughcertainly not the best or deepest of markets in the world, it has reasonable options for an averageindividual to investhissavings. Investorsneeds to invest and earn return on theiridleresources and generate a specifiedsum of money for a specific goal in life and make a provision for an uncertain future. Investment culture among the people of a country is an essential prerequisite for capital formation and the fastergrowth of an economy. Investment culture refers to the attitudes, perceptions, and willingness of individuals, and institutions in placingtheirsavings in variousfinancialassets, more popularlyknown as investmentsor Postal Savings. A study on preferences and level of Satisfaction thus assumes a greatersignificance in the formulation of policies for the development and regulation of savings inGeneral and protection and promotion of small and house-holdinvestors in particular. This isbecause of lack of awarenessamong the small and householdinvestors, poorinvestmentclimate, and loss of confidence of existinginvestors in Postal Savings. It isextremely important for the policymakers and regulatoryauthorities to understand the investors' perceptions, preferences, and theirconcerns on the market. Small savings of India Post are a popularinvestment option for risk-averse investors. Post office investmentsprovideflexibility and eventaxbenefits. Post office has long served as the backbone of communication and smalldeposits. For than 150 years the department of posts has played a pivotalrole in facilitating communication throughout the nation there by aiding in socio- economicdevelopment of the country. Post officervaried services; theirworkis not justrestricted to delivering mails. Theyacceptdeposits, provideretail services like sale of forms, bill collection etc, providesavingschemes, life insurancecoveretc, with a network of more than 1.5 lakh post offices across the country, India post offersvarious post office savingschemes. These are risk free investment options that are safe and secured and provideinvestorswith capital gains withouttaxdeductionat source (TDS). Variousinvestmentopportunities are available for an individual to hissaving and hecanchoose the appropriateinvestmentschemes, which suit hisneeds.

There are different types of opportunitiesprovided by manyfinancial institutions like commercial banks, cooperativebanks, post office savingbanks. Life insurance corporation public limitedcompany of all the 
abovementioned institutions, post office savingbanksplay vital role. It providesnumerousbenefits to the investors. Post office savingbanksis the largestsavings institutions in the country. With a view to mobilizingsavings of people withrelativelysmallincome and circulating in them a spirit of thrift and savings, the central Government has endeavoured to make the national savingsmovementpopular by offeringhighreturnsthanthosegiven by scheduledbanks. There are a number of attractive schemes, welldesigned to meet the Indi dual requirements of differentinvestors. Taxsavingfeatures of thoseschemesattracts the higherincome groups more thansmallsavers. The investment avenues provided by the post office are generallymarketable as they are saving media. The major instrument of post office schemesenjoytaxbenefitssuch as exemption of investment contribution or interestincomefromtax or both up to certain limits. Thesesavingschemes come at atrazine ratedwith nomination facilities and are transferable to any post office acrossIndia. Indianfamilies are known for theirsaving habits right fromhistoricalperiod. Indianhouseholdfamilies are characterised as quick saversant the same time they are riskaverters. Over, the yearsthere have been a shift experienced in the householdsaving and investment pattern. Householdsaving and investments are major contributors to the India's GDP (Gross DomesticProducts) i.e., 23.60 per cent and thishouseholdsaving and investment contribution of the Nation's GDP has rose 8.1 per cent in 2016 17. In recentyearsit has been observedthathouseholdsaving in banks, shares, debentures and in mutualfunds have increased and theirsaving in form of currency, provident funds has reduced .Presently in India, there are variousinvestmentschemes and opportunities are available for an individual to theirsavings and theycanchoose the appropriateinvestmentschemes, which suit hisneeds.

There are different types of opportunitiesprovided by manyfinancial institutions like commercial and co-operativebanks, India post, Life Insurance Corporation, public limitedcompanies etc. Among all the above institutions, Post Office Savings Bank schemesplay a vital role. It providesnumerousbenefits to the investors. Post office savingbankis the largestsavings institution in the country. Withaview to mobilizingsavings of people withrelativelysmallincome and circulating in them a spirit of thrift and savings, the central Government has endeavoured to make the National SavingsMovementpopular by offeringhighreturnsthanthosegiven by scheduledbanks. There are a number of attractive schemes, welldesigned to meet the individualrequirements of differentinvestors. Taxsavingfeatures of thoseschemesattracts the higherincome groups more thansmallsavers. The investment avenues provided by the post offices are generallymarketable as they are a saving media. The major instruments of post office schemesenjoytaxbenefitssuch as exemption of investment contribution or interestincomefromtax or both up to certain limits.

\section{Statement of the problem:-}

Among all the above institutions, Post Office Savings Bank schemes plays a vital role. It provides numerous benefits to the investors. Post office saving bank is the largest savings institution in the country. With a view to mobilizing savings of people with relatively small income and circulating in them a spirit of thrift and savings, the central Government has endeavoured to make the National Savings Movement popular by offering high returns than those given by scheduled banks. There are a number of attractive schemes, well designed to meet the individual requirements of different investors. Tax saving features of those schemes attracts the higher income groups more than small savers. The investment avenues provided by the post offices are generally marketable as they are a saving media. The major instruments of post office schemes enjoys tax benefits such as exemption of investment contribution or interest income from tax or both up to certain limits.

\section{Objectives of the study:-}

1.To study the awareness among investors about post office savings schemes in the study area.

2. To examine the current scenario of various post office schemes.

\section{Review of literature:-}

Kaboor (2010) study entitled "Determinants of Investor's Financial Literacy" made an attempt to study the sources of investment information and investment behaviour to investors and to measure the extent of financial literacy. The study found that the financial literary is not uniform among different groups of investors. The socio economic profile, information seeking behaviour and characteristics of investors causes such differences.

Singh (2011) research study aimed to analyse the saving and its investment pattern in rural areas. The study also tried to identify some of the important issues relating to the formal finance and investment development in rural measures taken by the Indian government for the economic development. The paper comes up with some of the 
suggestions which may improve the climate for savings and its investment in the state of Punjab and also across India.

Dhiraj Jain and Ruhika Kothari (2012) study made an attempt to identify the awareness, preferences, problem and attitudes of investor' towards various deposit schemes offered by the Post Office among 100 respondents of the Udaipur District. The result of the study revealed that the level of awareness of the respondents about various Deposits schemes are very low except Recurring Deposits and Post Office Saving Bank A/C.

KoreShashikant and Teli (2015) study examined the customer's attitude and perception towards post office savings schemes in Kolhapur district. The study found that Investor gives top priority to safety for their deposits hence next investment priority goes to nationalized bank. The result of the study concluded that there is a need to increase financial awareness about postal schemes, competitiveness, fast decision making, marketing activities and strategic planning to fight against private institutions.

Rakesh and Nalina (2017) study aimed to know and understand the individual investor behaviour. The study found that portfolios of investors, investment preferences, risk perception, investment pattern, awareness level, problems affecting investment behavior and problems encountered by the investors. The result of the study concluded that diversification of financial sector will give different varieties of investment opportunities to the individual investors.

Bhatia and Tyagi (2018) study aimed to examine the effects of Some Socioeconomic factors such as Income, Age, Level of Education, size of family on one's saving patterns. The study found that the level of savings is still poor due to low income, large family size or more number of dependents, joint family system and young working population.

\section{Tools Used For Analysis:-}

The following tools have been applied in the study: simple percentage method, Weighted Arithmetic Mean, standard deviation and Coefficient of variation.

\section{Sources Of Data:-}

The study has right combination of secondary data. The secondary data were sourced from books, journal articles, web-sites and also from thesis works.

\section{About India post office:- \\ 5.1Reason for development of post saving}

Inthe beginning of the 19th century, there were only a few banks and that too in big towns and cities. It was very difficult for the common man who wanted to save his small amount of money in the bank to go to a bank as he had to incur expenditure for the journey. Further, saving habit amongst the people was almost nil, and most of the people had their small savings in the form of gold and silver. On the other hand, the Government wanted to encourage savings because they were in dire need of money for various developmental activities, for strengthening military establishments and for carrying out administrative reforms. These factors compelled the Government to start Savings bank through the Post Office. Government Savings Bank was started in the three Presidency towns of Calcutta, Madras and Bombay in 1833, 1834 and 1835 respectively. In 1860, the Secretary of state for India initiated steps for empowering the post offices to undertake savings bank operations in India, similar to that of the U.K. But the Government was under organized and not mature enough to take upon such banking business. Some changes took place subsequently in the management of Savings Bank. Between 1863 and 1865, the management of the Savings Bank was transferred from Government Treasuries to the Presidency Bank, and each Presidency Bank framed its management. The deposit allowed was Rs. 500 in a year up to a maximum of Rs. 3000 and the interest rate was fixed at 3.75 percent per annum. In practice, the SB counters were kept open twice in a week .

Financial services of the post office form a profitable business today, although they were started as a supplementary income generating operation. Post offices render a plethora of agency services in addition to their basic duty of mail delivery. These services include savings Bank, Money Order, Postal Order and Postal Life Insurance. This helps the postal Department produce income to the extent of nearly 45per cent of its budget revenue. Savings bank work was undertaken by post offices on 1 April 1882 and the entire banking operations were kept under the supervision and management of postmasters. In Tamil Nadu, the introduction of POSB was confined to small places. The object of establishing SB was to extend banking facilities to millions of poor and middle class people living in the farthest 
corners of the country and to accumulate and invest their savings, and to use the same for the economic development of the country and also to meet the administrative needs and requirements of the Government. It also aimed at encouraging thrift.

India Post is committed to provide basic postal facilities throughout the country at an affordable price. A network of 1.55 lakh post offices in the country, the largest in the world, of which more than 1.39 lakh are in the rural areas, is indicative of this commitment. Rapid introduction of information technology has not only changed the way post offices do business the world over, but also the business that post offices do. In this era of fast developing information and communications technology, large scale induction and assimilation has become vital for the sustenance and growth of India Post.

\section{Introduction of Postal System in India in Historic Period:-}

The system of postal delivery varied from one country to another, it is believed that in India, Emperor Chandragupta Maurya who ruled the country between 321-297 BC (Before Christ) was the first to introduce a form of postal communication to dispatch confidential reports to distant posts in his empire. However, the first recorded mention in history is to be found in the writings of historian ZiadduinBarni. He mentions that Ala-ud- din Khilji of the Delhi Sultanate, who ruled Delhi over 700 years ago, organized a regular horse and foot runner service called harakuras in 1296 AD. These runners carried a baton with bells and ran across the allotted territory with mail. Runners changed after each mile and the post was delivered in record time.

Mughal Emperor Babar developed the horse courier service and maintained a regular courier postal service. At this time in France, a certain Monsieur de Velayer had the idea of creating a small post office and in 1653, he offered his customers' small pieces of paper mentioned 'receipt for the payment of transport'. Letters with these pieces attached were to be put into letterboxes to be later sent to their destinations . Warren Hastings, Governor of British India (1773-1784) opened the posts of the public in March 1774. In 1837, the imperial Post was established and granted a monopoly to provide efficient postal communications between the seat of government Calcutta and the principal provincial towns. In 1854, the GPOs of Calcutta, Bombay and Madras were brought under the authority of one Director General. A regular traveling post-office service was introduced in 1870 . Money order service was commenced in 1880 .

India has the largest postal network in the world. The country today has 155015 post offices of which, 139144 are in rural areas and 23344 in urban areas. On an average, a post office serves an area of $21.21 \mathrm{sq} \mathrm{km}$ and a population of 7175. The Postal Department has about 2.18 lakh departmental employees and about 2.76 lakh GraminDakSevaks. India has been divided into 22 postal circles, each circle headed by a Chief Postmaster General. The Postal Staff College India (PSCD), Ghaziabad meets the training and development needs of Indian Postal Service Officers and other Gazetted Officers.

\section{Different Saving Products of Indian Post Office:-}

Different Saving Products of Indian Post Office has been briefly discussed in this section.

I. Saving Account Scheme: Post office saving bank account (POSB) is the oldest and most popular postal saving instrument. Any individual can open a POSB A/C with a minimum balance of Rs-50/. A pass book is provided to the $\mathrm{A} / \mathrm{C}$ holder and Cheque facility is also available for POSB is 4 per cent. This Account is regulated by The Government Savings Bank Act of 1873.

II. Time deposit account: Post office offers time deposit for one year, two year, three year and five year.

III. Recurring Deposit account (RD): Offers a monthly investment option with a handsome return at the end of five years with option to extend the account period. Insurance cover facility is also available with some conditions.

IV. Monthly Income Scheme: under this scheme the severs make a lump- sum deposit, which gives him a monthly interest. The minimum deposit in case of single depositor is Rs 1000/ and in case of joint depositor it is Rs $1500 /$.

V. National Savings Certificate: This is a tax exempted certificate sold by post office with a minimum investment of Rs 100/ and having no maximum limit. Trust and HUF are not allowed to invest in NSC.

VI. Public provident fund scheme: This is a tax advantage 15 years scheme with a minimum deposit of Rs $500 /$ in a financial year and a maximum of Rs 70,000/ per year. Withdrawal is allowed after expiry of five years from the date of initial deposit. 
VII. Senior Citizens Savings Scheme (SCSS): Offers fixed investment option for senior citizens for a period of five years, which can be extended, at a higher rate of interest that are paid in quarterly instalments.

VIII. KisanVikasPatra (KVP): KisanVikasPatra is a saving certificate scheme in which the amount invested doubles in 110 months (i.e. 9 years \&amp; 2 months). It is available in denominations of Rs. 1000, 5000, 10000 and Rs. 50000. Minimum deposit is Rs. 1000/- and there is no maximum limit.

IX. Postal Life Insurance: besides above mention saving schemes the Indian post offering life insurance services since 1884. Initially the service was limited only to the employee of post \&amp; telegram department but due to its popularity the service was later on extended to the employees of some other departments and banks also. It was opened for all people in the year 1995.

X. Rural Postal Life Insurance: To extend the life insurance service to the rural public the post office extended the service to rural areas in 1995. The prime objective of the scheme is to provide insurance cover to the rural public in general and to benefit weaker sections and women workers of rural areas in particular and also to spread insurance awareness among the rural population.

XI. SukanyaSamriddhiAccounts(SSA):SukanyaSamriddhi Account Yojana offers a small deposit investment for the girl children as an initiative under 'BetiBachaoBetiPadhao' campaign. This yojana is to facilitate girl children proper education and carefree marriage expenses.

\section{Leveraging India Post's Strength:-}

The financial services of India Post are administered by two major entities - Postal Life Insurance Directorate (PLI) and Financial Services Division (FSD). The PLI Directorate deals with PLI and Rural PLI products, while the FSD deals with all the other financial services. India Post offers the following financial services:

i. $\quad$ Post-Office Savings Bank (POSB) services

ii. $\quad$ Postal Life Insurance services-Postal Life Insurance (PLI) and Rural Postal Life Insurance (RPLI)

iii. Pension payments to employees of post, telecom, coal-miners and railways.

iv. Money orders and postal orders

v. New financial services, such as international money transfers with Western Union, distribution of mutual funds, distribution of government securities, electronic funds transfer, warrant payment and others.

The Government of India had framed various saving schemes with the objective to provide fully secured and attractive investment opportunity to the public. It another main purpose is to mobilize huge resource to the government exchequer for the development of the country. These post office schemes are attractive to the public as they offer good tax benefits and higher returns. These schemes were framed under the government saving banks Act, 1873, Government savings certificates Act, 1959 and public provident fund Act, 1968. The main financial services offered by the department op posts are the post office savings bank. It is the largest and oldest banking service institution in the country. The department of posts operates the post office savings scheme function on behalf of the ministry of finance, Government of India. Under this scheme, more than 20.50 crores savings account are operated. These accounts are operated through more than 1,54,000 post offices across the country.

Anaysis and interpretation:-

Performance Analysis in various schemes

PFOFILE OF SAVINGS BANK SCHEMES DURING 2015-2016 AND 2016-2017

Table 1:-Traditional saving schemes(Investment values in lacks)

\begin{tabular}{|l|l|l|l|l|l|l|l|l|l|l|}
\hline Year & $07-08$ & $08-09$ & $09-10$ & $10-11$ & $11-12$ & $12-13$ & $13-14$ & $14-15$ & $15-16$ & $16-17$ \\
\cline { 1 - 8 } No of schemes & 691 & 780 & 886 & 965 & 1158 & 1253 & 1335 & 1660 & 1630 & 1862 \\
\hline $\begin{array}{l}\text { Savings } \\
\text { Accounts }\end{array}$ & 661 & 744 & 753 & 834 & 59 & 939 & 1106 & 1229 & 1222 & 1227 \\
\hline RD Accounts & 60 & 93 & 94 & 94 & 112 & 142 & 162 & 167 & 167 \\
\hline TD Accounts & 119 & 90 & 251 & 269 & 242 & 229 & 220 & 211 & 195 & 167 \\
\hline MIS Accounts & 232 & 247 & 5 & 4 & 4 & 3 & 3 & 3 & 3 & 3 \\
\hline $\begin{array}{l}\text { NSS Accounts } \\
(87 \text { \& 92) }\end{array}$ & 5 & 5 & 23 & 23 & 23 & 24 & 24 & 24 & 25 & 25 \\
\hline PPF Accounts & 21 & 22 & 12 & 14 & 12 & 11 & 11 & 9 & 10 & 11 \\
\hline $\begin{array}{l}\text { Sr.Citizens } \\
\text { Saving Scheme }\end{array}$ & 8 & 10 & & & & & & & & \\
\hline
\end{tabular}




\begin{tabular}{|l|l|l|l|l|l|l|l|l|l|l|}
\hline (SCSS) & & & & & & & & & & \\
\hline Time Deposit & 7 & 4 & 3 & 3 & 3 & 3 & 3 & 2 & 2 & 2 \\
\hline Fixed Deposit & 0.06 & 0.07 & 0.07 & 0.14 & 0.21 & 0.08 & 0.03 & 0.03 & 0.03 & 0.03 \\
\hline
\end{tabular}

Source: Annual report

The above table describes the problems regarding investment in postal savings scheme in post office. Out of 10years financial position in Indian post office saving schemes. In financial year 2007-2008 the traditional saving schemes are performed $193.76 \%$. In upcoming years the investors investing performance was increased is compared for 2016-2018 the mean percentage level is increased 381.89.

Table 2:- Recent saving schemes(Investment values in lacks)

\begin{tabular}{|l|l|l|l|l|l|l|l|l|l|}
\hline Year & $08-09$ & $09-10$ & $10-11$ & $11-12$ & $12-13$ & $13-14$ & $14-15$ & $15-16$ & $16-17$ \\
\hline No of schemes & & & & & & & & & \\
\hline NSC VIII & 5.53 & 15.39 & 5.46 & 5.51 & 6.47 & 7.51 & 0.85 & 0.88 & 0.87 \\
\hline KVP & 16.63 & 20.87 & 15.86 & 15.40 & 12.84 & 10.67 & 0.85 & 0.65 & 0.54 \\
\hline
\end{tabular}

Source: Annual report

From the above table the opinions of investors about the various saving schemes offered by the post office. Out of 11 schemes particularly above mentioned two type of saving schemes are very useful for all type of investors. The S.D value is compared in these two type of account. NSC certificate investors are 4.31.Kisan vikas patria is compared to the NSC certificate investors excess value of S.D is 7.69.Investing attitude compare to NSC is increased to Kisanvikaspatria.Coefficient value are compared the theses two type of account holder, Kisanvikas patria account holder 80.11 for compared with NSC certificate 80.11 .

Table 3:-femalesaving schemes(Investment values in lacks)

\begin{tabular}{|l|l|l|l|}
\hline Year & $14-15$ & $15-16$ & $16-17$ \\
\hline No of schemes & & & \\
\hline suganyasmithi & 24.86 & 79.68 & 99.19 \\
\hline
\end{tabular}

Source: Annual report

From the above table the opinion of investors of female children saving scheme is very useful all type of investors. Introduced in 2014-2015 number of account holder is 24.86.Investors investing behaviour increased gradually increased upcoming years. coefficient of variation value increased all years compared with introducing years. values are $24.86,79.68$ and 99.19 for all years.

\section{Findings:-}

It indicated that safety and security as their first objective in choosing the investment alternatives. The next opportunities of small investors in the selection of post savings avenues are regular return from the investment. These two objectives are followed by capital growth, tax benefits and liquidity and marketability in the descending order. It is understood from these facts that house hold investor prefer to invest in those products which offer safety and security, regular return and capital growth. The household small investors are least bothered about tax benefits and liquidity \& marketability. They have indicated the children education as their first purpose of investment alternatives. The next purpose of investment household investors is medical expenses from the investment made. The investors are indicated tax planning as their investment purpose. These three purposes are followed by maintaining retirement life, marriage and buying property in the descending order.

\section{Suggestion:-}

There is an explosion in growth of middle class families due to double income group families and increase in number of working women, hence this group will plays vital role in the investment market. Efforts should be made to attract the women investors by providing right information and knowledge about the post office saving schemes through advertisements.

\section{Conclusion:-}

They are highly aware of post office monthly income scheme, post office recurring deposit, post office time deposit and post office saving account. Only a very few investors are quite unaware of post office saving schemes. The main 
objectives of the sample investors are regular return and safety and security, followed by tax benefits, capital growth and liquidity. Children education and marriage are the main purpose of investment of the respondents, followed by medical expenses, tax planning, maintaining retirement life and buying property.

\section{Reference:-}

1. Thulasipriya. B (2015),A Study on the Investment Preference of Government Employees on Various Investment Avenues, International Journal of Management Research and Social Science, Volume 2, Issue 1, ISSN 2394-6407(Print), ISSN 2394-6415(Online),PP.9-16, January -March.

2. B.Saranya And G.B.Karthikeyan(2015),AStudy on Preferences and Level of Satisfaction Towards Post Office SavingsSchemes (WithSpecial Reference To Coimbatore City), International Journal of Management (Ijm) Volume No. 6, Issue No. 1, ISSN: 0976-6502 (Print), ISSN: 0976-6510 (Online), PP. 771-775 ,January.

3. India Post offers a wide range of tax-saving options for the risk-averse, The Financial Express, $1{ }^{\text {st }}$ September, 2015.http://www.financialexpress.com/industry/banking-finance/tax-talk-india-post-offers-a-wide-range-of-taxsaving-options-for-the-risk-averse/128404/.

4. https://www.indiapost.gov.in/Financial/Pages/Content/Post-Office-Saving-Schemes.aspx 